wh node-negative breast cancer who have oestrogen receptor positive tumours. N Eingl Y Med 1989:320:479-8

5 Fisher B, Brown A Wolmark N, Redmond C, Wickerham DL, W'ittliff J, t al. Prolonging tamoxifen therapy for primary breast cancer: Findings from the national surgical adjusant breast and bowel project clinical trial. Ann Intern Med 1987:106:649-54

6 Osborne CK. Hobbs K, Clark GM. Effect of estrogens and antiestrogens on growth of human breast cancer cells in athymic nude mice. Cancer $R e s$ $1985 ; 45: 584-90$.

Jordan $\mathrm{V}^{\mathrm{C}}$. Chemosuppression of breast cancer with tamoxifen: laboratory evidence and future clinical investigations. Cancer Invest 1988;6:5-11.

8 Powles TJ, Hardy JR, Ashley SE, Farrington (iM, Cosgrove D, Davey JB, et al. A pilot trial to evaluate the acute toxicity and feasibility of tamoxifen for prevention of breast cancer. Br f Cancer 1989;60:126-31.

9 Bruning PF, Bonfrer JM, Hart AA, De Jong-Bakker M, Linders D, Van Loon $\mathrm{J}$ et al. Tamoxifen, serum lipoproteins and cardiovascular risk. $\mathrm{Br} \mathcal{f}$ Cancer 1988;58:497-9.

10 Turner RT, Wakeley GK, Hannon KS, Bell NH. Tamoxifen inhibits osteoclast mediated resorption of trabecular hone in ovarian hormone deficient rats. Endocrinology 1988:122:1146-50

11 Love RR, Mazess RB, Tormay DC, Barden HS, Newcomb PA, Jordan VC. Bone mineral density in women with breast cancer treated with adjuvant tamoxifen for at least two years. Breast Cancer Res Treat 1988;12:297-301.

12 Turkin S, Siris E, Seldin D, Flaster E, Hyman G, Lindsay R. Effects of tamoxifen on spinal bone density in women with breast cancer. J Natl Cancer Inst 1989:81:1086-8.
13 Breast Cancer Trials Committee. Adjuvant tamoxifen in the management of operable breast cancer: the Scottish trial. Lancet 1987;ii: 171-6.

It Furr BJA, Jordan VC. The pharmacology and clinical uses of tamoxifen. Pharmucol the 1984:25:127-205.

15 Bertelli G, Pronzato P, Amoroso D, Cusimano MP, Conte PF, Montagna G et al. Adjuvant tamoxifen in primary breast cancer: influence on plasma lipids and antithrombin III levels. Breast Cancer Res Treat 1988;12:307-10.

16 Caleffi M, Fentiman IS, Clark GM, Wang DY, Needham J, Clark K, et al. Effect of tamoxifen on oestrogen binding, lipid and lipoprotein concentrations and blood clotting parameters in premenopausal women with breas pain. $\mathcal{F}$ Endocrinol 1988:119:335-9.

17 Love RR, Newcomb PA, Wiebe DA, Surawicz TS, Jordan VC, Carbone PP, et al. Effects of tamoxifen therapy on lipid and lipoprotein levels in postmenopausal patients with node-negative breast cancer. $\mathcal{F}$ Natl Cancer Inst 1990;82:1327-32.

18 Henderson BE, Paganini-Hill A, Ross RK. Estrogen replacement therapy and protection from acute myocardial infarction. Am f Obstet Gynecol 1988;159: $312-7$

19 Bourne T, Hillard TC, Whitehead MI, Crook D, Campbell S. Oestrogens, arterial status, and postmenopausal women. Lancet 1990; i: 1470-1.

20 Reaven GM. Role of insulin resistance in human disease. Diabetes 1988;37: 1595-607.

21 Dahan R, Espie M, Mignot L, Houlbert D, Chanu B. Tamoxifen and arterial thrombosis. Lancet 1985 ; i:638.

(Accepted 24 fune 1991)
Department of Public

Health Medicine, St

Thomas's Campus, United

Medical and Dental

Schools, London SE1 7EH

Martin C Gulliford, MFPHM,

Wellcome Trust training fellow

Ann Petruckevitch, MSC,

lecturer in medical statistics

Peter G J Burney, FFPHM,

reader in public health

medicine

Correspondence to: $\mathrm{Dr}$ Gulliford.

BMF 1991;303:437-40

\title{
Survival with bladder cancer, evaluation of delay in treatment, type of surgeon, and modality of treatment
}

\author{
Martin C Gulliford, Ann Petruckevitch, Peter G J Burney
}

\section{Abstract}

Objective-To determine whether length of delay before treatment; specialty and grade of the surgeon; and use made of surgery, radiotherapy, and chemotherapy influenced the survival of patients with cancer of the bladder, after adjusting for case severity.

Design-Retrospective cohort study.

Setting-South East and South West Thames health regions.

Patients -609 men aged under 75 resident in the South Thames regions who had been registered as new cases of bladder cancer in 1982, 35 of whom were excluded, leaving 574 eligible patients. Analysis was based on $75 \%$ retrieval rate for case notes.

Main outcome measures-Duration of survival from date of diagnosis of the bladder tumour.

Results-10 prognostic variables were used to adjust for case severity. The median delay from referral to first treatment was $\mathbf{4 8}$ (interquartile range 27-84) days. Treatment after a short delay was associated with shorter survival because of the early treatment of more severe cases. Consultants treated $68 \%$ of patients, trainee surgeons treated less severe cases. Initial treatment was by a urologist in $67 \%$ of cases, but the specialty of the surgeon was not associated with prognosis. The associations of radiotherapy, cystectomy, and systemic chemotherapy with survival were interpreted in terms of selection bias as well as therapeutic effect.

Conclusions-Case severity was the most important influence on survival and influenced length of delay before treatment, grade and specialty of the surgeon, and main treatment allocation. After adjusting for case severity variations in these processes of care were not strongly associated with variations in survival.

\section{Introduction}

In England and Wales there are substantial variations in mortality from conditions which should be amenable to medical treatment ${ }^{12}$; variations in survival with cancer have also been reported. ${ }^{34}$ Cancer of the bladder is one of the most common cancers, ${ }^{5}$ and health care is thought to influence the prognosis. ${ }^{6}$ An analysis of cancer registry data for the South Thames regions showed systematic variation in the survival of patients with bladder cancer according to district health authority of residence (A Walker et al, unpublished data). One explanation for this observation could be that the quality of health care varied sufficiently to influence survival of these patients. ${ }^{7}$ The outcome of treatment for cancer of the bladder might be influenced by several characteristics of health care, including the length of delay before treatment ${ }^{6}$; the grade and specialty of the surgeon ${ }^{89}$; and the use made of surgery, radiotherapy, and chemotherapy.$^{10}$ These were relevant factors to investigate, given current problems with long waiting times, ${ }^{11}$ staffing and surgical specialties, ${ }^{12}$ and organisation of cancer treatment services. ${ }^{13}$ This study aimed at determining whether, after allowing for the severity of the underlying disease, survival of patients with cancer of the bladder in the South Thames regions was influenced by these processes of care.

\section{Patients and methods}

The patients in the study were men aged below 75 , resident in the South Thames regions, and registered with cancer of the bladder at the Thames Cancer Registry in 1982. The registry supplied a list of 609 names believed to fulfil the entry criteria. We excluded 35 men after examining their hospital records: seven in whom a diagnosis of bladder cancer had not been confirmed, four who were not resident in the South Thames regions at the time of diagnosis, and 24 whose disease was not first diagnosed in 1982. Thus 574 patients were eligible for further investigation. After consultants' approval had been obtained we abstracted data from the patients' hospital notes and radiotherapy records at 71 hospitals and 11 radiotherapy centres with standard data collection forms.

The patient's age was calculated as 1982 minus the year of birth and was included as a continuous variable. The presence of associated disease was noted from the record of the first hospital admission. The categories none, cardiac, respiratory, renal, and other (specify) were reduced for analysis to "comorbidity present" and "comorbidity absent." The histological extent of tumour invasion was classed according to the Inter- 
national Union Against Cancer (UICC) categories $^{14}$ as non-invasive ( $\mathrm{pTa}$ ), superficially invasive ( $\mathrm{pT} 1)$, and muscle infiltrating (pT2 or greater). It was not always clear, however, that an adequate biopsy specimen containing muscle had been obtained. The extent of invasion could not be classified for some patients because the histopathology report was not available or because the extent of invasion was not mentioned; a category was included for tumours whose extent of invasion was not classified or not known. The results of intravenous urography and blood urea and haemoglobin concentrations were reduced to the categories shown in table II. The results of other staging investigations performed at the initial assessment (including computed tomography, ultrasonography, radioisotope scans, and conventional radiography) were classified together as not done, normal, or not known, and abnormal. The total delay before treatment was calculated from the date of the initial referral letter to the date of first treatment. The outpatient delay was taken as the time from the referral letter to the date of the first hospital consultation. The hospital delay was calculated as the time from the first hospital consultation to the first treatment. The delay before radiotherapy was calculated from the date of the initial referral letter to the date of the first radiotherapy treatment.

TABLE I-Distribution of tumour by $p$ T category and one, five, and seven year survival rates

\begin{tabular}{lrccc}
\hline & & \multicolumn{3}{c}{ Survival (\%) } \\
\cline { 3 - 5 } pT grade & No(\%) & 1 year & 5 year & 7 year \\
\hline pTa & $150(35)$ & 95 & 80 & 72 \\
pT1 & $85(20)$ & 94 & 69 & 54 \\
? UT2 & $90(21)$ & 61 & 23 & 21 \\
Unclassified & $105(24)$ & 82 & 53 & 46 \\
\hline
\end{tabular}

Overall $\chi^{2}=103 \cdot 3, \mathrm{df}=3, \mathrm{p}<0 \cdot 001$

Trend across pT categories $\chi^{2}=88 \cdot 5, \mathrm{df}=1, \mathrm{p}<0 \cdot 001$

TABLE II-Variables characterising case severity. Figures are hazard rates (95\% confidence intervals) relative to first category of each variable, each adjusted for the other variables and significance of overall association of variable with survival (likelihood ratio test)

\begin{tabular}{|c|c|c|c|}
\hline Variable & No of patients & $\begin{array}{l}\text { Hazard rate ( } 95 \% \\
\text { confidence interval) }\end{array}$ & $\mathrm{p}$ Value \\
\hline Age (years) & 430 & $1.04(1.02$ to 1.07$)$ & $<0.001$ \\
\hline \multicolumn{4}{|l|}{ Comorbidity: } \\
\hline Absent & 310 & $1 \cdot 00$ & \multirow[t]{3}{*}{$0 \cdot 012$} \\
\hline Present & 108 & $1.62(1 \cdot 16$ to $2 \cdot 25)$ & \\
\hline Not known & 12 & $0.67(0.24$ to 1.89$)$ & \\
\hline \multicolumn{4}{|l|}{ Symptoms at referral: } \\
\hline Haematuria & 289 & $1 \cdot 00$ & \multirow[t]{3}{*}{0.032} \\
\hline Other, haematuria, or both & 102 & $1.60(1 \cdot 12$ to $2 \cdot 30)$ & \\
\hline Not known & 39 & $1.43(0.77$ to 2.64$)$ & \\
\hline \multicolumn{4}{|l|}{ pT category: } \\
\hline pTa & 150 & 1.00 & \multirow[t]{4}{*}{0.002} \\
\hline pTl & 85 & $1.34(0.79$ to 2.28$)$ & \\
\hline$\geqslant \mathrm{pT} 2$ & 90 & $2.52(1.51$ to 4.18$)$ & \\
\hline Unclassified and not known & 105 & $1.78(1.07$ to 2.94$)$ & \\
\hline \multicolumn{4}{|l|}{ Tumour grade: } \\
\hline Well differentiated & 154 & $1 \cdot 00$ & \multirow{4}{*}{0.004} \\
\hline Moderately differentiated & 116 & $1.44(0.86$ to 2.43$)$ & \\
\hline Poorly differentiated & 105 & $2 \cdot 42(1.40$ to $4 \cdot 18)$ & \\
\hline Not known & 55 & $2 \cdot 23(1.21$ to $4 \cdot 13)$ & \\
\hline \multicolumn{4}{|l|}{ Tumour appearance at cystoscopy: } \\
\hline Papillary & 223 & $1 \cdot 00$ & \multirow[t]{4}{*}{0.010} \\
\hline Solid & 108 & $1 \cdot 75(1.18$ to $2 \cdot 58)$ & \\
\hline Other & 22 & $2.36(1.26$ to 4.40$)$ & \\
\hline Not known & 77 & $1.43(0.93$ to $2 \cdot 19)$ & \\
\hline \multicolumn{4}{|l|}{ Findings on intravenous urography: } \\
\hline No abnormality & 79 & $1 \cdot 00$ & \multirow{4}{*}{0.010} \\
\hline Filling defect & 192 & $1.02(0.64$ to 1.64$)$ & \\
\hline Ureteric obstruction & 59 & $1.67(0.95$ to 2.94$)$ & \\
\hline Other and not known & 100 & $1.78(1.09$ to 2.91$)$ & \\
\hline \multicolumn{4}{|l|}{ Urea concentration $(\mathrm{mmol} / \mathrm{l})$ : } \\
\hline$<5$ & 120 & $1 \cdot 00$ & \multirow[t]{4}{*}{0.037} \\
\hline$\geqslant 5-<8$ & 163 & $0.84(0.56$ to 1.25$)$ & \\
\hline$\geqslant 8$ & 64 & $1.53(0.96$ to 2.43$)$ & \\
\hline Not known & 83 & $0.72(0.39$ to 1.34$)$ & \\
\hline \multicolumn{4}{|l|}{ Haemoglobin concentration $(\mathrm{g} / \mathrm{l})$ : } \\
\hline$\geqslant 140$ & 230 & $1 \cdot 00$ & \multirow[t]{4}{*}{0.003} \\
\hline$\geqslant 120<140$ & 77 & $1.02(0.67$ to 1.54$)$ & \\
\hline$<120$ & 46 & $2.51(1.55$ to 4.07$)$ & \\
\hline Not known & 77 & $1 \cdot 27(0.70$ to $2 \cdot 27)$ & \\
\hline \multicolumn{4}{|l|}{ Other staging investigations: } \\
\hline Not done, normal, not known & 401 & $1 \cdot 00$ & \multirow[t]{2}{*}{0.004} \\
\hline Abnormal & 29 & $2.25(1.33$ to 3.81$)$ & \\
\hline
\end{tabular}

Survival rates were estimated by the product limit method $^{15}$; the log rank test was used to test the significance of differences between groups. For surviving patients the survival time was censored at the date of the last follow up or at 17 May 1989 (the date on which patient data were obtained from the registry), whichever was the sooner. The date of death was ascertained from hospital records and from the records of the registry (which also obtains information from the NHS central register). The proportional hazards model was used to estimate the associations of explanatory variables with survival. ${ }^{15}$ The associations with survival of prognostic variables intrinsic to the patient and tumour were first evaluated. A stepwise procedure with backwards elimination was used to select those variables which were independently associated with survival. The 10 prognostic variables selected by the stepwise procedure were used in subsequent analyses to adjust the associations of health care variables with survival for case severity. Thus case severity was defined by indentifying the characteristics of the patient which were independently associated with survival. Associations of health care variables with survival were estimated both in univariate (unadjusted) analyses and in multiple regression analyses in which adjustment was made for the 10 variables used to define case severity. Hazard rates relative to a baseline category were estimated for the categories of categorical variables. The values for hazard rates are associated with survival such that values greater than one indicate an increased risk of death and values less than one indicate a reduced risk of death. The overall significance of the association of the variable with survival was tested using the likelihood ratio. For clarity hazard rates for categories of variables recorded as "not known" were omitted from the data presented in table III and were not included in the likelihood ratio test.

\section{Results}

Case notes were retrieved for $466 / 574(81 \%)$ patients. The retrieval rate was $246 / 281(88 \%)$ for surviving patients and 220/293 (75\%) for deceased patients. In 36 patients ( 31 who died and five who survived) the date of diagnosis was missing so the survival analysis was based on a $430 / 574(75 \%)$ retrieval rate. The 466 patients whose data were available for analysis had a median age of 67 years (range 22-74 years), and at least one associated disease was recorded in $110(24 \%)$ at the initial hospital assessment. The histological type of the cancer was transitional cell type in $408(88 \%)$ patients. Table I shows survival rates by pT category. A stepwise procedure selected 10 characteristics of patient or tumour which were independently associated with survival (table II). These variables together were used to adjust for case severity in subsequent analyses. Three variables were associated with shorter survival in univariate but not in multiple regression analyses: non-transitional cell type, symptoms other than haematuria recorded at the first hospital consultation, and raised serum creatinine concentration.

There was a weak trend towards worsening prognosis with increasing duration of symptoms before referral, but the duration of symptoms was not mentioned in a third of cases and the association with survival was not significant (table III). Table IV shows the durations of delays before treatment. Patients with the shortest total or hospital delay had a worse prognosis than did those treated after longer delays (table III). Adjusting for case severity accounted for the associations of total delay and of hospital delay with survival. This suggested that patients with severe disease were given priority for treatment. Patients who were referred by general practitioners for admission to hospital (and 
TABLE III-Associations of health care processes with survival, unadjusted and adjusted for case severity. Figures are hazard rates (95\% confidence intervals) relative to first category * and overall significance of association of variable with survival

\begin{tabular}{|c|c|c|c|c|c|}
\hline \multirow[b]{2}{*}{ Variable } & \multirow[b]{2}{*}{ No of patients } & \multicolumn{2}{|c|}{ Unadjusted survival } & \multicolumn{2}{|c|}{ Survival adjusted for case severity } \\
\hline & & $\begin{array}{c}\text { Hazard rate }(95 \% \\
\text { confidence interval) }\end{array}$ & p Value & $\begin{array}{c}\text { Hazard rate }(95 \% \\
\text { confidence interval) }\end{array}$ & p Value \\
\hline \multicolumn{6}{|c|}{ Duration of symptoms at referral (weeks): } \\
\hline$\leqslant 2$ weeks & 114 & $1 \cdot 00$ & $0 \cdot 249$ & $1 \cdot 00$ & $0 \cdot 062$ \\
\hline$>2 \leqslant 8$ weeks & 82 & $1 \cdot 34(0 \cdot 86$ to $2 \cdot 10)$ & & $1.27(0.80$ to $2 \cdot 02)$ & \\
\hline$>8$ weeks & 94 & $1.39(0.91$ to $2 \cdot 14)$ & & $1.75(1 \cdot 10$ to $2 \cdot 79)$ & \\
\hline Not known & 140 & & & & \\
\hline \multicolumn{6}{|l|}{ Type of referral: } \\
\hline Outpatient & 339 & $1 \cdot 00$ & $<0 \cdot 001$ & $1 \cdot 00$ & 0.586 \\
\hline Inpatient & 57 & $2.07(1.43$ to 3.01$)$ & & $1 \cdot 13(0 \cdot 74$ to $1 \cdot 74)$ & \\
\hline Not known & 34 & & & & \\
\hline \multicolumn{6}{|c|}{ Grade of doctor seen at initial hospital consultation: } \\
\hline Consultant & 260 & $1 \cdot 00$ & $0 \cdot 176$ & $1 \cdot 00$ & $0 \cdot 878$ \\
\hline Junior doctor & 126 & $1.25(0.91$ to 1.73$)$ & & $1.03(0.73$ to 1.45$)$ & \\
\hline Not known & 44 & & & & \\
\hline \multicolumn{6}{|c|}{ Type of follow up after initial hospital consultation: } \\
\hline Outpatient & 154 & $1 \cdot 00$ & $<0.001$ & $1 \cdot 00$ & $0 \cdot 165$ \\
\hline Waiting list & 195 & $1.19(0.85$ to 1.67$)$ & & $1.18(0.83$ to 1.70$)$ & \\
\hline Inpatient & 59 & $2.65(1.75$ to 4.01$)$ & & $1.57(0.99$ to 2.50$)$ & \\
\hline Not known & 22 & & & & \\
\hline \multicolumn{6}{|l|}{ Total delay before treatment: } \\
\hline$<27$ days & 85 & 1.00 & 0.095 & $1 \cdot 00$ & $0 \cdot 193$ \\
\hline$\geqslant 27-<48$ days & 89 & $0.59(0.37$ to 0.93$)$ & & $0.62(0.37$ to 1.03$)$ & \\
\hline$\geqslant 48-<84$ days & 90 & $0.65(0.41$ to 1.01$)$ & & $0.85(0.51$ to 1.41$)$ & \\
\hline$\geqslant 84$ days & 90 & $0.63(0.40$ to 1.00$)$ & & $1.01(0.60$ to 1.70$)$ & \\
\hline Not known & 76 & & & & \\
\hline \multicolumn{6}{|l|}{ Hospital delay before treatment: } \\
\hline$<14$ days & 94 & $1 \cdot 00$ & $0 \cdot 014$ & $1 \cdot 00$ & $0 \cdot 085$ \\
\hline$\geqslant 14-<26$ days & 92 & $0.51(0.32$ to 0.79$)$ & & $0.60(0.37$ to 0.98$)$ & \\
\hline$\geqslant 26-<51$ days & 95 & $0.60(0.39$ to 0.92$)$ & & $0.68(0.43$ to 1.09$)$ & \\
\hline$\geqslant 51$ & 101 & $0.59(0.39$ to 0.91$)$ & & $1.02(0.63$ to 1.65$)$ & \\
\hline \multirow{2}{*}{\multicolumn{6}{|c|}{ Grade of surgeon at initial cystoscopy: }} \\
\hline & & & & & \\
\hline Consultant & 313 & 1.00 & 0.018 & $1 \cdot 00$ & 0.872 \\
\hline Trainee surgeon & 79 & $0.62(0.40$ to 0.94$)$ & & $1.04(0.65$ to 1.65$)$ & \\
\hline Not known & 38 & & & & \\
\hline \multicolumn{6}{|l|}{ Specialty of surgeon: } \\
\hline Urology & 302 & 1.00 & 0.570 & $1 \cdot 00$ & $0 \cdot 264$ \\
\hline General surgery & 93 & $1.20(0.85$ to 1.68$)$ & & $1.27(0.86$ to 1.89$)$ & \\
\hline General surgery and urology & 30 & $1 \cdot 15(0.65$ to 2.03$)$ & & $1.53(0.83$ to 2.81$)$ & \\
\hline Other and not known & 5 & & & & \\
\hline \multicolumn{6}{|l|}{ Type of operation: } \\
\hline Transurethral resection & 359 & 1.00 & 0.038 & $1 \cdot 00$ & $0 \cdot 048$ \\
\hline Total cystectomy & 10 & $2 \cdot 28(1.06$ to $4 \cdot 86)$ & & $2 \cdot 83(1 \cdot 17$ to $6 \cdot 83)$ & \\
\hline Cystectomy after radiotherapy & 14 & $1.76(0.90$ to 3.46$)$ & & $1 \cdot 27(0.60$ to $2 \cdot 70)$ & \\
\hline Other & 39 & $1.58(1.00$ to 2.50$)$ & & $1.70(1.04$ to 2.77$)$ & \\
\hline Not known & 8 & & & & \\
\hline \multicolumn{6}{|l|}{ Radiotherapy: } \\
\hline None & 255 & $1 \cdot 00$ & $<0.001$ & 1.00 & 0.013 \\
\hline At initial assessment & 122 & $5.50(3.95$ to 7.64$)$ & & $1.62(0.99$ to 2.66$)$ & \\
\hline Later in first year & 20 & $5.32(3.09$ to $9 \cdot 16)$ & & $2 \cdot 82(1.52$ to $5 \cdot 22)$ & \\
\hline After one year & 33 & $2.56(1.53$ to 4.29$)$ & & $1.35(0.73$ to 2.45$)$ & \\
\hline \multicolumn{6}{|l|}{ Chemotherapy: } \\
\hline None & 340 & $1 \cdot 00$ & $<0.001$ & $1 \cdot 00$ & $0 \cdot 041$ \\
\hline Intravesical & 67 & $0.50(0.31$ to 0.80$)$ & & $0.66(0.39$ to 1.11$)$ & \\
\hline Systemic & 18 & $2.79(1.66$ to 4.68$)$ & & $1.86(1.01$ to 3.44$)$ & \\
\hline Not known & 5 & & & & \\
\hline
\end{tabular}

${ }^{\star}$ Hazard rates for variables recorded as not known are not shown and were not included in the likelihood ratio test.

who were therefore treated with a short delay) had a worse outcome than those referred for outpatient assessment (table III). Similarly, patients admitted to hospital after the first consultation had a worse prognosis than those placed on the waiting list. These associations were also accounted for by adjusting for case severity.

Patients were seen by a consultant at the initial hospital consultation on 263 (56\%) occasions. The first cystoscopy was performed by a consultant on $318 / 466$ $(68 \%)$ occasions. The risk of death was less for patients in whom the initial cystoscopy was performed by a trainee surgeon (table III), but this was accounted for by adjusting for case severity; trainees were treating less severe cases. A urologist was responsible for the patient's initial management on 310/466 (67\%) occasions.

TABLE IV-Delay times before treatment

\begin{tabular}{lcc}
\hline Delay & $\begin{array}{c}\text { No of observations } \\
\text { (No eligible) }\end{array}$ & $\begin{array}{c}\text { Median (interquartile } \\
\text { range) delay (days) }\end{array}$ \\
\hline $\begin{array}{l}\text { Delay before initial treatment: } \\
\text { Total delay }\end{array}$ & $354(466)$ & $48(27-84)$ \\
$\begin{array}{l}\text { Outpatient delay } \\
\text { Hospital delay }\end{array}$ & $361(466)$ & $14(4-26)$ \\
$\begin{array}{l}\text { Delay before radiotherapy: } \\
\text { Referral at initial assessment } \\
\text { Referral later in first year of } \\
\text { follow up }\end{array}$ & $382(466)$ & $26(14-51)$ \\
\hline
\end{tabular}

There was no association between specialty of surgeon and survival. After allowing for case severity the use of radiotherapy was not associated with survival, except in patients who were referred not at the initial assessment but after a subsequent cystoscopy in the first year of follow up. Cystectomy was employed infrequently and tended to be associated with a worse prognosis. Systemic chemotherapy was used in a few patients and was associated with a worse prognosis, after allowing for case severity. The use of intravesical chemotherapy was associated with longer survival overall because it was usually used in patients who developed frequent recurrences during prolonged follow up.

\section{Discussion}

In this study, variables characterising the severity of the condition ${ }^{16-19}$ were strongly associated with survival. Case severity was an important influence on treatment allocation but after adjusting for severity there was little evidence to suggest that processes of care contributed greatly to the variation in survival of patients with cancer of the bladder. In this observational study it is necessary to acknowledge potential biases, including the possibility that some confounding variables may not have been fully evaluated.

The patients were sampled from a population based registry. We excluded those aged over 75 , in whom 
health care was less likely to have had an important impact on the prognosis, and 24 patients whose first diagnosis was not in 1982, so that the investigation was confined to incident cases. We have shown that the non-retrieval of case notes was to some extent systematic $^{20}$; in particular, deceased patients and patients treated at teaching hospitals were underrepresented because of the difficulty of finding their notes. Thus it may not be entirely justified to assume that the patients whose notes were obtained were representative of those whose notes were not. In addition, the retrieval rate for case notes varied systematically among health districts and hospitals and direct evaluation of the factors responsible for variation in survival among districts was therefore not possible.

Wallace and Harris ${ }^{6}$ reported that the three year survival with invasive cancer of the bladder was $60 \%$ when the duration of symptoms before treatment was less than four weeks but that it fell to $25 \%$ when the history was longer. This observation has not been confirmed subsequently. ${ }^{2122}$ Our results suggest that patients with the worst prognosis were selected for early treatment, and there was little evidence to suggest that the prognosis deteriorated with increasing delay. Similarly, the results suggest that less severe cases in patients were selected for treatment by trainee surgeons: after allowing for severity there was no evidence that the grade or specialty of the surgeon had an effect on patient survival.

Patients received treatment over a varying period of follow up. The analysis presented here provides a crude summary of the use of different procedures and their associations with survival. The results must be interpreted cautiously, both in terms of the factors which influence selection for treatment and in terms of possible therapeutic effectiveness. Although adjustment was made for case severity, this may not entirely have accounted for confounding of disease severity with treatment allocation. The separate contributions of selection bias and therapeutic effectiveness to associations with survival therefore cannot be clearly quantified. Radiotherapy was used as the principal mode of treatment for invasive tumours. After adjusting for severity an adverse prognosis was associated with referral not at the first cystoscopy but later in the first year of follow up. The extent of tumour invasion could be classified for 15 patients in this group, 11 of these had tumours initially classed as pTa or pTl. These tumours might have been understaged at the initial operation, although we did not have data to show whether an adequate biopsy specimen containing muscle was obtained. ${ }^{23}$ There was no evidence that the overall prognosis was worse for the patients referred later as the unadjusted hazard rate was similar to that for patients referred for radiotherapy at the initial assessment. The infrequent use of cystectomy is consistent with the uncertainty over its use, ${ }^{24}$ but the results obtained suggest that further evaluation of the use of this operation would be justified. A few patients were treated with systemic chemotherapy, mainly in the context of a clinical trial whose negative results have been reported..$^{25}$ The results of our study suggest that selection for this form of treatment was an independent marker of case severity.

The release of hospital mortality statistics in the United States has provided a new stimulus to the investigation of health care characteristics associated with mortality. ${ }^{26}$ In epidemiological studies case severity has been the most important influence on mortality. ${ }^{27} 280$ Our findings are consistent with this and provide some reassurance that the length of delay before treatment, the training and experience of surgeons, and the appropriateness of the use made of major treatment modalities were not factors which contributed substantially to the variation of survival of patients treated for cancer of the bladder in these two regions. Evaluation by peer review might be more likely to identify departures from ideal practice which adversely affected prognosis. ${ }^{x 9}$ The strong dependence of mortality on case severity makes it a weak measure of the quality of health care.$^{30}$ Measures of outcome other than survival are therefore needed for monitoring and for use in clinical trials. ${ }^{31}$

We thank all of the clinicians who allowed us to examine their patients' notes, the medical records staff who helped with retrieving case notes, the Thames Cancer Registry for supplying data for the study, and Professor W W Holland for his support and encouragement. The authors were supported by the Wellcome Trust and the Department of Health.

1 Holland WW. The European Community atlas of "avoidable death." Oxford: Oxford University Press, 1988

2 Charlton JRH, Hartley RM, Silver R, Holland WW. Geographical variation in mortality from conditions amenable to medical intervention in England and mortality from conditions a
Wales. Lancet 1983;i:691-6.

3 Office of Population Censuses and Surveys. Cancer statistics survival 1971-5. London: HMSO, 1982. (Series MBI, No 9 .)

4 Silman AJ, Evans SJW. Regional differences in survival from cancer. Community Medicine 1981;3:291-7.

5 Office of Population Censuses and Surveys. Review of the nutional cancer registration system 1990. London: HMSO, 1990:9.

6 Wallace DM, Harris DL. Delay in treating bladder tumours. Lance 1965 ;ii:332-4.

7 Karjalainen S. (ieographical variation in cancer patient survival in Finland chance, confounding or effect of treatment. $\mathcal{F}$ Epidemiol Community Healt 1990;44:210-4.

8 Buck N, Devlin HB, Lunn JN. The report of a confidential enquiry into perioperative deaths. London: Nuffield Provincial Hospitals Trust, 1987.

9 Second-best prostatectomy. BMF 1980;280:590.

10 Raghavan D, Shipley WU, Garnick MB, Russell PJ, Richie JP. Biology and management of bladder cancer. $N$ Engl F Med 1990;322:1129-38.

11 Delamothe T. Waiting lists up again. BMF 1990;301:1011.

12 Trunker D. Report to the Council of the Association of Surgeons of Great Britain and Ireland. BM7 1989;299:31-3.

13 Mould RF. Cancer treatment services (radiotherapy) in London. Lancet $1986 ;: 1385$.

14 Spiessl B, Beahrs OH, Hermanek P, Hutter RVP, Sciebe O, Sobin LH, et al, eds. UICC TNM atlas. Illustrated guide to the TNM/pTNM classification of eds. UICC TNM atlas. Mllustrated guide to the TNM/PTN
malignant tumours. Berlin: Springer-Verlag, 1989:245-50.

malignant tumours. Berlin: Springer-Verlag, $989: 245-50$.
15 Dixon WJ. BMDP statistical sofiware manual. Vol. 2. Berkeley, California: University of California Press, 1990:759-806.

16 Aso Y, Andersen L, Soloway M, Bouffioux C, Chisholm G, Debryne F, et al. Prognostic factors in superficial bladder cancer. Prog Clin Biol Res 1986;162A:257-69

17 Richards B, Aso Y, Bollack C, Fossa S, Koontz W, Matsuda M, et al. Prognostic factors in infiltrating bladder cancer. Prog Clin Biol Res 1986; 162A:271-86

18 Mameghan H, Fisher R. Invasive bladder cancer: prognostic factors and results of radiotherapy with and without cystectomy. Br $\mathcal{F}$ Urol 1989;63: 251-8.

19 Abel PD. Prognostic indices in transitional cell carcinoma of the bladder. $B r \mathcal{F}$ Urol 1988;62:103-9.

20 Gulliford MC, Petruckevitch A, Burney PGJ. Hospital case notes and medica audit: evaluation of non-response. $B M F$ 1991;302:1128-9.

21 Mommsen S, Aagaard J, Sell A. Presenting symptoms, treatment delay and survival in bladder cancer. Scand $\mathcal{F}$ Urol Nephrol 1983;17:163-7.

22 Bishop MC. The dangers of a long urological waiting list. $\mathrm{Br} f \mathrm{Urol}$ 1990;65:433-40.

23 Soloway MS. Selecting initial therapy for bladder cancer. Cancer 1987;60: $502-13$.

24 Hope-Stone HF, Oliver RTD, England HR, Blandy JP. T3 bladder cancer: salvage rather than elective cystectomy after radiotherapy. Urology 1984;24: $315-20$.

25 Shearer RJ, Chilvers CED, Bloom HJG, Bliss JM, Horwich A, Babiker A Adjuvant chemotherapy in $\mathrm{T} 3$ carcinoma of the bladder; a prospective trial. A preliminary report. $\mathrm{Br} f$ Urol 1988;62:558-64.

26 Dubois RW, Brook RH, Rogers WH. Adjusted hospital death rates: potential screen for quality. Am $\mathcal{I}$ Public Health 1987;77:1162-7.

27 Green J, Wintfeld N, Sharkey P, Passman LJ. The importance of severity of illness in assessing hospital mortality. $\mathcal{F} A M A$ 1990;263:241-6.

28 Park RE, Brook RH, Kosecoff J, Keesey J, Rubenstein L, Keeler E, et al. Explaining variations in hospital death rates: randomness, severity of illness quality of care. FAMA 1990;264:484-90.

29 Dubois RW, Rogers WH, Moxley JH, Draper D, Brook RH. Hospital inpatient mortality: is it a predictor of quality. N Engl F Med 1987;317 $1674-80$.

30 Hopkins A. Measuring the quality of medical care. London: Royal College of Physicians of London, 1990.

31 Tonkin K, Tannock I. Evaluation of response and morbidity following treatment of bladder cancer. In: Raghavan D, ed. The management of bladder cancer. London: Arnold, 1988:228-44.

(Accepted 28 June 1991)

\section{Correction}

Physiotherapy for stress urinary incontinence: a national survey

An authors' error occurred in this paper by Jill Mantle and Eboo Versi (30 March, p 755). The last sentence in the results section "prognostic features" should read "On the optimistic side . . "young and premenopausal' (40) were the most common features" (not postmenopausal as printed). 